\title{
Evaluating Awareness and Practices Towards Diabetes and Diabetic Retinopathy in Adult Patients Attending the Eye Clinic in a Tertiary Academic Hospital in Jordan
}

This article was published in the following Dove Press journal: Clinical Ophthalmology

Faisal Khatib'

Nafez Abu Tarboush'

Nakhleh Abu-Yaghi $\mathbb{D D}^{2}$

Mohammad Alazzam ${ }^{3}$

Abdallah Al-Ani ${ }^{3}$

Baraa Mafrachi (D) $^{3}$

'Department of Biochemistry and Physiology, School of Medicine, The University of Jordan, Amman, Jordan;

${ }^{2}$ Department of Special Surgery Ophthalmology Division, School of Medicine, The University of Jordan, Amman, Jordan; ${ }^{3}$ School of Medicine, The University of Jordan, Amman, Jordan
Correspondence: Nakhleh Abu-Yaghi Department of Special Surgery Ophthalmology Division, School of Medicine, The University of Jordan, Amman, I1942, Jordan

Email n.abuyaghi@ju.edu.jo

\begin{abstract}
Aim and Background: Awareness of diabetes mellitus (DM) and its complications, particularly diabetic retinopathy (DR), is one of the main factors of early detection and improved management. This study aims to assess the level of awareness of DM type 2 complications in a cohort of Jordanian patients, with special emphasis on DR.

Methods: A total of 176 consecutive patients with DM type 2 attending the ophthalmology clinic at Jordan University Hospital were included in the study. Each participant responded to a questionnaire which assessed their awareness and behaviors towards DM type 2 and DR. Results: A total of 176 individuals with diabetes responded to the invitation to participate. They were $93(52.8 \%)$ males and $83(47.2 \%)$ females. Mean age $( \pm$ SEM) for the study population was $60.6( \pm 0.82)$ years. Of all participants, $93.8 \%$ were aware that diabetes can affect the eyes. Only $4.5 \%$ reported that DR could occur without symptoms and/or loss of vision. Symptoms affecting the eyes were the main cause behind attending the ophthalmology clinic in $60.8 \%$ of the cases. The awareness score of participants for DM and DR ranged from 4 to 15 out of 20 with a mean score of 11.4/20. Statistically significant relationships of awareness mean score were observed with gender, educational level, employment status, insurance status, Hemoglobin $(\mathrm{Hb}) \mathrm{A} 1 \mathrm{c}$ level, and dyslipidemia as a co-morbidity $(\mathrm{p}<0.05)$. Binary logistic regression revealed disease duration and $\mathrm{HbAlc}$ as the main predictive factors of having DR.

Conclusion: Among this cohort of Jordanian individuals with diabetes, awareness towards DM and DR was relatively low, and patient practices did not correlate with perceived awareness. Awareness scores correlated with $\mathrm{HbA} 1 \mathrm{c}$ readings and higher educational levels among other variables. Emphasis on communication strategies and patient education is essential in establishing efficient screening programs and effective strategies to curtail visual impairment and other complications of the diabetes pandemic.
\end{abstract}

Keywords: diabetic retinopathy, diabetes mellitus, HbA1c, awareness, practices

\section{Introduction}

Diabetes Mellitus (DM) is a metabolic disorder characterized by dysregulation of insulin action or secretion leading to hyperglycemia. The International Diabetes Federation maintains that DM is prevalent in $8.6 \%$ of adults worldwide. ${ }^{1}$ The Middle Eastern and North African (MENA) region exhibits an even higher prevalence rate of $9.6 \%$, which is expected to increase to $12 \%$ by $2045 .^{2}$ This 
difference in prevalence rates is attributed to the urbanization process, increased rates of obesity and the expanding aging populations in the MENA region. ${ }^{2}$ Parallel with the global trends, the prevalence of DM in Jordan is increasing at an alarming rate, reaching an astonishing $13.1 \%{ }^{3}$

The burden of DM and its systemic complications is enormous, inflicting an overwhelming strain on the national and international economies. ${ }^{4}$ Diabetic Retinopathy (DR) is a progressive blood vessel disorder of the retina and is the most common ocular disease in diabetic eyes. ${ }^{5}$ Recently, DR is considered the leading cause of vision loss worldwide. ${ }^{6}$ A Jordanian study reported a DR prevalence rate of $64 \%$ among diabetic patients, which is expected considering the high rates of DR in the entire region. ${ }^{7}$ Complications resulting from DM can be mitigated with appropriate education and management, which could significantly prevent end organ damage and halt the progression of the disease. ${ }^{8}$

Adequate patient awareness plays a vital role in the early diagnosis and management of DR. ${ }^{9}$ In fact, appropriate awareness and practices decreases the burden of morbidity associated with DR, in addition to being a costeffective method of DR management. ${ }^{10}$ Global awareness levels of diabetic patients towards DR are variable. ${ }^{11-15}$ Local Jordanian studies report awareness levels ranging from $50 \%$ to $80 \%$, associated with an overall trend of incompliance. $^{11,16}$

Thus, it is of vital importance to ensure that the diabetic populace has adequate knowledge and awareness of diabetes and its complications. In particular, DR can occur without visual symptoms and patients not undergoing regular screening can irreversibly lose vision before symptoms ensue. It should be noted that there is no national program for screening of DM type 2 in Jordan, let alone its complications. Thus, we aim to evaluate the awareness and practices of patients with diabetes towards the disease and its complications, particularly DR, in an effort to formulate recommendations addressing the awareness gaps of such a vulnerable population.

\section{Methodology}

\section{Study Design and Sampling}

A cross-sectional study involving 176 patients was conducted at Jordan University Hospital ophthalmology clinics between August and November of 2016. The study included patients with DM type 2, who could speak and understand Arabic, irrespective of their DR status. Patients whom are diagnosed with DM type 1, younger than 18 years old or refused to participate in the study were excluded. The study utilized convenience nonprobability sampling as to amass an appropriate population to detect statistical significance. The diagnosis of DR was reached through a clinical examination conducted by an expert ophthalmologist. The study utilized convenience non-probability sampling as to amass an appropriate population to detect statistical significance. Using a $5 \%$ margin of error and a power of $90 \%$, power analysis revealed that a minimum of $20 \mathrm{DR}$ patients would be needed to detect statistical significance in comparison to non-DR controls. ${ }^{17,18}$

\section{Data Collection}

Patients meeting the inclusion criteria were subjected to a questionnaire, after signing a written consent form. The validity of the questionnaire was assessed by expert specialists heavily involved in the care of patients with diabetes, while some constituents of the questionnaire were adopted from similar literature. ${ }^{19-21}$ The questionnaire involved three major sections. The first collected socio-demographic variables and DM type 2-related characteristics including, gender, age, body mass index (BMI), educational level, employment status, insurance status, and comorbidities, as well as the duration of DM and the latest Hemoglobin ( $\mathrm{Hb})$ A1c level. Data provided by participants as well as information regarding required investigations have been verified through reviewing participants' hospital records. ${ }^{17,18}$ The second section of the questionnaire evaluated patients' practices by asking participants about the following parameters: frequency of physical exercise, regular weight checkup, DM diet status, level of compliance to diet, having a glucose checking device at home, frequency of glucose checking, periodic annual visit to the ophthalmologist, and the cause of the first clinic visit. The questionnaire's final section evaluated patients' awareness about DM and DR. This section consisted of 20 questions assessing the following: life style modifications, DM's systemic complications, the effects of DM on vision, signs and symptoms of DR and the frequency of recommended clinic visits. All of the questions were binary in nature except the last two. A scoring system was applied, with each exemplary answer given one point and zero points for incorrect answers. Afterwards, a total awareness score was calculated for each patient with a maximum score of 20 points. Participants' awareness was categorized according to the 
awareness score as: $<50 \%$ poor awareness, 50-75\% moderate awareness, $>75 \%$ adequate awareness.

\section{Data Analysis}

Data were analyzed using the statistical package for social sciences (SPSS) version 20 (IBM Corporation, Armonk, NY, USA). Categorical data were presented as count and percentages whereas quantitative data were represented by means and standard error of the mean (SEM). For categorical outcomes, univariate analysis was conducted through Pearson Chi-square testing, in order to find significant associations between participants' socio-demographic variables and different practices with presence or absence of DR. Also, mean awareness scores were compared to the participants' socio-demographic variables according to presence or absence of DR using one-way ANOVA statistical test with Duncan post hoc analysis. Binary logistic regression was utilized to determine the predictors of the presence of DR. Two-independent sample $t$ test was run to compare two groups. Any differences or associations with a p-value less than 0.05 were considered significant.

\section{Ethical Consideration}

Ethical approval was granted from the Institutional Review Board at Jordan University Hospital (Ethical approval number: 278/2020/67). Written informed consent was obtained from all patients after explaining the aim of the study and the nature of their participation.

\section{Results}

\section{Demographic and Clinical Characteristics of Study Participants}

A total of 176 patients with DM type 2 were included in the study. The mean age ( \pm SEM) of the study sample was 60.6 ( \pm 0.82$)$ years, ranging from 25 to 88 years. Males constituted $52.8 \%$ of the entire sample. The majority of the study population was overweight or obese $(42.0 \%$, or $44.9 \%$, respectively). Almost half of the study population (89 patients $(50.6 \%))$ had secondary school education, and $63(35.8 \%)$ of the patients had a bachelor's degree. The most common comorbidity among the cohort was hypertension (66.4\%). Among the recruited cohort, 88 (50.0\%) participants had DR. The majority of patients with DR were males (58\%), belonged to the 60-69 years-old age group (37.5\%), overweight $(47.7 \%)$, have completed secondary school education (45.4\%), retired (44.3\%), diagnosed with DM type 2 for more than 10 years $(86.3 \%)$, and exhibit HbAlc levels of more than $8 \%$ (57.9\%). Our results show that the duration of DM and the level of HbA1c were significantly different between patients with and without DR $(\mathrm{p}<0.01)$. Participants' general and DMrelated characteristics are reported in Table 1.

\section{Awareness of the Study Participants Toward DM Type 2 and DR}

Overall, participants have moderate awareness regarding DR $(57 \%)$ where awareness means score $( \pm$ SEM) was $11.4( \pm 0.2)$ and scores ranged from (4-15) out of 20. Table 2 illustrates the frequency of correct responses to each of the awareness items. Almost all patients (98.3\%) were aware that DM could negatively affect different body systems and organs. Of the involved organs, $93.8 \%$ and $76.1 \%$ of the patients were aware that DM can affect the eye and the kidney, respectively. Nonetheless, only $4.5 \%$ and $10.2 \%$ were aware that DM may result in sexual dysfunction and peripheral neuropathy, respectively. Despite that $96.0 \%$ of the study participants were aware that patients with uncontrolled DM might end up with blindness, only $22.7 \%$ reported that DR may present with vision loss. Furthermore, a meager $4.5 \%$ were aware that DR may occur without blurred vision and/or vision loss.

Table 3 portrays that gender, educational level, employment status, insurance, level of $\mathrm{HbAlc}$, and the presence of concomitant dyslipidemia, were statistically significant contributors to the awareness score (all $\mathrm{p}<0.01)$. Moreover, there were no significant differences between mean awareness scores and the presence of DR or the duration of DM.

\section{Practices of Patients with Type 2 DM Toward Their Disease and Its Relationship to DR}

Our results maintain that the frequency of physical exercise and regular weight checkup were statistically similar between patients with and without DR. Possessing a home glucose checking device and the frequency of glucose level checking were both statistically insignificant between the two groups. We observed that patients who are following a diabetic dietary regimen and who were compliant with the diet were much more likely to have DR $(\mathrm{p}<0.01)$. Ophthalmologist visits due to visual symptoms were statistically different between the study groups $(p<0.05)$. Table 4 details the results of participants' practices. 
Table I Sociodemographic Variables and Diabetic Retinopathy

\begin{tabular}{|c|c|c|c|c|c|}
\hline Parameter & Categories & Total $\mathbf{N}$ & No DR N (\%) & DR N (\%) & $P$ value* \\
\hline Gender & $\begin{array}{l}\text { Female } \\
\text { Male }\end{array}$ & $\begin{array}{l}83 \\
93\end{array}$ & $\begin{array}{l}46(55.4) \\
42(45.2)\end{array}$ & $\begin{array}{l}37(44.6) \\
51(54.8)\end{array}$ & 0.174 \\
\hline Age (years) & $\begin{array}{l}<40 \\
40-49 \\
50-59 \\
60-69 \\
70-79 \\
>80\end{array}$ & $\begin{array}{l}10 \\
9 \\
54 \\
66 \\
30 \\
7\end{array}$ & $\begin{array}{l}5(50.0) \\
6(66.7) \\
23(42.6) \\
33(50.0) \\
16(53.3) \\
5(71.4)\end{array}$ & $\begin{array}{l}5(50.0) \\
3(33.3) \\
31(57.4) \\
33(50.0) \\
14(46.7) \\
2(28.6)\end{array}$ & 0.608 \\
\hline BMI & $\begin{array}{l}<25 \\
25-29 \\
\geq 30\end{array}$ & $\begin{array}{l}23 \\
74 \\
79\end{array}$ & $\begin{array}{l}\text { I5 (65.2) } \\
32(43.2) \\
41(51.9)\end{array}$ & $\begin{array}{l}8(34.8) \\
42(56.8) \\
38(48.1)\end{array}$ & 0.168 \\
\hline Educational level & $\begin{array}{l}\text { None } \\
\text { Secondary education } \\
\text { Undergraduate } \\
\text { Postgraduate }\end{array}$ & $\begin{array}{l}9 \\
89 \\
63 \\
15\end{array}$ & $\begin{array}{l}5(55.6) \\
49(55.1) \\
30(47.6) \\
4(26.7)\end{array}$ & $\begin{array}{l}4(44.4) \\
40(44.9) \\
33(52.4) \\
\text { I I }(73.3)\end{array}$ & 0.219 \\
\hline Employment & $\begin{array}{l}\text { Unemployed } \\
\text { Employed } \\
\text { Retired }\end{array}$ & $\begin{array}{l}70 \\
31 \\
75\end{array}$ & $\begin{array}{l}38(54.3) \\
14(45.2) \\
36(48.0)\end{array}$ & $\begin{array}{l}32(45.7) \\
17(54.8) \\
39(52.0)\end{array}$ & 0.630 \\
\hline Insurance & $\begin{array}{l}\text { Uninsured } \\
\text { Insured }\end{array}$ & $\begin{array}{l}14 \\
162\end{array}$ & $\begin{array}{l}6(42.9) \\
82(50.6)\end{array}$ & $\begin{array}{l}8(57.1) \\
80(49.4)\end{array}$ & 0.577 \\
\hline Duration of DM & $\begin{array}{l}<5 \text { Years } \\
5-10 \text { Years } \\
11-20 \text { Years } \\
>20 \text { Years }\end{array}$ & $\begin{array}{l}31 \\
35 \\
69 \\
41\end{array}$ & $\begin{array}{l}24(77.4) \\
30(85.7) \\
25(36.2) \\
9(22.0)\end{array}$ & $\begin{array}{l}7(22.6) \\
5(14.3) \\
44(63.8) \\
32(78.0)\end{array}$ & $<0.001$ \\
\hline $\mathrm{HbAlc}$ & $\begin{array}{l}<7 \\
7-7.9 \\
8-8.9 \\
>9\end{array}$ & $\begin{array}{l}53 \\
37 \\
40 \\
46\end{array}$ & $\begin{array}{l}38(71.7) \\
15(40.5) \\
12(30.0) \\
23(50.0)\end{array}$ & $\begin{array}{l}15(28.3) \\
22(59.5) \\
28(70.0) \\
23(50.0)\end{array}$ & $<0.001$ \\
\hline Comorbidity & $\begin{array}{l}\text { Hypertension } \\
\text { Heart disease } \\
\text { Dyslipidemia }\end{array}$ & $\begin{array}{l}117 \\
62 \\
100\end{array}$ & $\begin{array}{l}53(45.3) \\
29(46.8) \\
51(51.0)\end{array}$ & $\begin{array}{l}64(54.7) \\
33(53.2) \\
49(49.0)\end{array}$ & $\begin{array}{l}0.079 \\
0.528 \\
0.761\end{array}$ \\
\hline
\end{tabular}

Notes: ${ }^{*} P$ values for the Gender and Insurance items were calculated by Fischer's exact test. All other items were subjected to Chi-square testing.

\section{Binary Logistic Regression Analysis of Factors Associated with Diabetic Retinopathy}

Disease status as having DR or not has been adjusted for HbAlc plasma level and DM 2 disease duration among our participants. Each variable was statistically significant at the 95\% confidence level. Hence, each is considered predictive for DR occurrence along the course of DM type 2 disease; however, with different impact explained by the coefficients for each variable (Refer to Table 5). Results indicate that specific predictive factors of having DR as a result of DM type 2 are: duration of DM type 2 of more than 10 years compared to durations which are less and HbAlc level of $8 \%$ or above.

\section{Discussion}

Our results show that a high percentage of Jordanian patients with diabetes recruited in this study were aware that DM could affect their eyes (93.8\%). This result is similar to previous studies conducted in Jordan in which awareness to the ocular effects of DM type 2 ranges from 
Table 2 Correct Responses to Knowledge Subscales

\begin{tabular}{|c|c|c|c|}
\hline Q \# & Q Text & $\mathbf{N}$ & $\%$ \\
\hline I. & $\begin{array}{l}\text { Do you think that DM will have an effect on } \\
\text { your vision in the future time? }\end{array}$ & 175 & 99.4 \\
\hline 2. & $\begin{array}{l}\text { Do you know that DM has complications on } \\
\text { many organs and systems? }\end{array}$ & 173 & 98.3 \\
\hline 3. & $\begin{array}{l}\text { Is there any advantage of regularly exercising } \\
\text { after developing DM? }\end{array}$ & 167 & 96 \\
\hline 4. & Do you think that DM can cause you blindness? & 169 & 96 \\
\hline 5. & $\begin{array}{l}\text { Do you know that DM might result in } \\
\text { pathology in the eyes? }\end{array}$ & 165 & 93.8 \\
\hline 6. & $\begin{array}{l}\text { Do you think that a good blood sugar control is } \\
\text { important for preventing DM complications? }\end{array}$ & 164 & 93.2 \\
\hline 7. & $\begin{array}{l}\text { Do you think that exercise decreases the risk of } \\
\text { developing DM? }\end{array}$ & 156 & 88.6 \\
\hline 8. & $\begin{array}{l}\text { Do you believe that weight plays an important } \\
\text { role in the development of DM and its } \\
\text { complications? }\end{array}$ & 134 & 76.1 \\
\hline 9. & $\begin{array}{l}\text { Do you know that DM might result in } \\
\text { pathology in the kidneys? }\end{array}$ & 134 & 76.1 \\
\hline 10. & $\begin{array}{l}\text { Do you believe that weight gain is an important } \\
\text { risk factor for developing DM? }\end{array}$ & 129 & 73.3 \\
\hline II. & $\begin{array}{l}\text { When should a DM patient see an } \\
\text { ophthalmologist? }\end{array}$ & 91 & 51.7 \\
\hline 12. & $\begin{array}{l}\text { Do you know that DM might result in } \\
\text { pathology in the heart? }\end{array}$ & 77 & 43.8 \\
\hline 13. & $\begin{array}{l}\text { How many times a DM patient should test his } \\
\text { vision? (annually) }\end{array}$ & 69 & 39.2 \\
\hline 14. & $\begin{array}{l}\text { Do you know that DM might result in } \\
\text { pathology in the vessels? }\end{array}$ & 63 & 35.8 \\
\hline 15. & $\begin{array}{l}\text { Do you know that DM might result in } \\
\text { pathology in the extremities? }\end{array}$ & 60 & 34.1 \\
\hline 16. & Is retinal bleeding a sign/symptom of DR? & 40 & 22.7 \\
\hline 17. & $\begin{array}{l}\text { Do you know that DM might result in } \\
\text { pathology in the peripheral nerves? }\end{array}$ & 18 & 10.2 \\
\hline 18. & Is blurred vision a sign/symptom of DR? & 10 & 5.7 \\
\hline 19. & $\begin{array}{l}\text { Do you know that DM might result in sexual } \\
\text { dysfunction? }\end{array}$ & 8 & 4.5 \\
\hline 20. & Is vision loss a sign/symptom of DR? & 8 & 4.5 \\
\hline
\end{tabular}

Note: Average \pm SEM (II.4 \pm 0.2$)$.

$88.2 \%$ to $98.3 \%$, and that around $50.4 \%$ of Jordanian patients with diabetes are familiar with DR. ${ }^{9,10}$ Similar
Table 3 Relationship Between Socio-Demographic Variables and Knowledge Scores

\begin{tabular}{|c|c|c|c|}
\hline Parameter & Categories & Mean \pm SEM & $P$ value* \\
\hline \multirow[t]{2}{*}{ Gender } & Female & $10.5 \pm 0.24$ & 0.008 \\
\hline & Male & $11.3 \pm 0.20$ & \\
\hline \multirow[t]{6}{*}{ Age (years) } & $<40^{\mathrm{a}}$ & $10.6 \pm 0.75$ & 0.092 \\
\hline & $40-49^{b}$ & $10.8 \pm 0.64$ & \\
\hline & $50-59^{b}$ & $11.3 \pm 0.23$ & \\
\hline & $60-69^{\mathrm{b}}$ & $11.0 \pm 0.28$ & \\
\hline & $70-79^{\mathrm{b}}$ & $|0.8 \pm 0.4|$ & \\
\hline & $>80^{\mathrm{b}}$ & $8.7 \pm 0.92$ & \\
\hline \multirow[t]{3}{*}{ BMI } & $<25$ & $11.0 \pm 0.43$ & 0.962 \\
\hline & $25-30$ & $10.9 \pm 0.26$ & \\
\hline & $>30$ & $10.9 \pm 0.23$ & \\
\hline \multirow[t]{4}{*}{ Educational level } & None $^{a}$ & $8.8 \pm 0.74$ & $<0.001$ \\
\hline & School ${ }^{b}$ & $10.6 \pm 0.23$ & \\
\hline & College $e^{b, c}$ & $11.4 \pm 0.24$ & \\
\hline & Postgraduate $^{c}$ & $12.0 \pm 0.36$ & \\
\hline \multirow[t]{3}{*}{ Employment } & Unemployed $^{\mathrm{a}}$ & $10.3 \pm 0.28$ & 0.003 \\
\hline & Employed $^{\mathrm{b}}$ & $|1.6 \pm 0.3|$ & \\
\hline & Retired $^{\mathrm{b}}$ & $11.2 \pm 0.22$ & \\
\hline \multirow[t]{2}{*}{ Insurance } & Uninsured & $9.5 \pm 0.72$ & 0.009 \\
\hline & Insured & $11.0 \pm 0.16$ & \\
\hline \multirow[t]{4}{*}{ Duration of DM } & $<5$ Years & $10.9 \pm 0.29$ & 0.743 \\
\hline & $5-10$ Years & $10.6 \pm 0.39$ & \\
\hline & II-20 Years & $1 \mathrm{I} .1 \pm 0.27$ & \\
\hline & $>20$ Years & $10.9 \pm 0.33$ & \\
\hline \multirow[t]{4}{*}{$\mathrm{HbAlc}{ }^{* *}$} & $<7^{\mathrm{a}}$ & $11.2 \pm 0.22$ & 0.014 \\
\hline & $7-7.9^{\mathrm{a}}$ & $\mid I .1 \pm 0.41$ & \\
\hline & $8-8.9^{\mathrm{a}}$ & $11.3 \pm 0.35$ & \\
\hline & $>9^{\mathrm{b}}$ & $10.0 \pm 0.30$ & \\
\hline \multirow[t]{2}{*}{ Disease status } & DR & $11.0 \pm 0.24$ & 0.457 \\
\hline & No DR & $10.8 \pm 0.22$ & \\
\hline \multirow[t]{6}{*}{ Comorbidities } & Hypertension (Yes) & $10.9 \pm 0.20$ & \\
\hline & Hypertension (No) & $10.8 \pm 0.27$ & 0.747 \\
\hline & Heart disease (Yes) & $10.9 \pm 0.28$ & \\
\hline & Heart disease (No) & $10.9 \pm 0.20$ & 0.940 \\
\hline & Dyslipidemia (Yes) & $11.2 \pm 0.21$ & \\
\hline & Dyslipidemia (No) & $10.5 \pm 0.24$ & 0.015 \\
\hline
\end{tabular}

Notes: $* P$ values for Gender, Insurance and Disease status items were calculated by Student's $t$-test. All other items were subjected to ANOVA. **HbAlc levels are

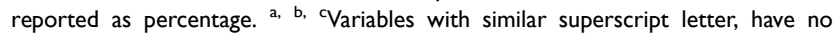
significant differences among them using Duncan post hoc analysis.

studies have shown different rates in countries like Saudi Arabia, India, and Oman (50-75\%), while higher numbers were reported in Japan and Australia (98\%, 96\%, respectively). ${ }^{11-14}$ Such variation is attributed to the 
Table 4 Practices of Patients with or without Diabetic Retinopathy

\begin{tabular}{|c|c|c|c|c|c|}
\hline Parameter & Statement & $\begin{array}{l}\text { Total } \\
\text { n (\%) }\end{array}$ & $\begin{array}{l}\text { No Diabetic Retinopathy } \\
\text { n (\%) }\end{array}$ & $\begin{array}{l}\text { Diabetic Retinopathy } \\
\text { n (\%) }\end{array}$ & $P$ value* \\
\hline Physical Exercise & $\begin{array}{l}\text { Daily } \\
\text { Never } \\
\text { Sometimes } \\
\text { Weekly }\end{array}$ & $\begin{array}{l}32 \\
103 \\
33 \\
8\end{array}$ & $\begin{array}{l}17(53.1) \\
53(51.5) \\
13(39.4) \\
5(62.5)\end{array}$ & $\begin{array}{l}15(46.9) \\
50(48.5) \\
20(60.6) \\
3(37.5)\end{array}$ & 0.532 \\
\hline Assesses weight regularly & & 111 & $55(49.5)$ & $56(50.5)$ & 0.876 \\
\hline On diabetic diet & & 64 & $22(34.4)$ & $42(65.6)$ & 0.002 \\
\hline Compliance to diet & $\begin{array}{l}\text { Sometimes } \\
\text { committed } \\
\text { Mostly committed } \\
\text { Strictly committed }\end{array}$ & $\begin{array}{l}13 \\
24 \\
27\end{array}$ & $\begin{array}{l}6(46.2) \\
6(25.0) \\
10(37.0)\end{array}$ & $\begin{array}{l}7(53.8) \\
18(75.0) \\
17(63.0)\end{array}$ & 0.009 \\
\hline $\begin{array}{l}\text { Have a glucose checking device at } \\
\text { home }\end{array}$ & & 152 & 74 (48.7) & $78(5 \mid .3)$ & 0.380 \\
\hline $\begin{array}{l}\text { Frequency of glucose level } \\
\text { assessment }\end{array}$ & $\begin{array}{l}\text { I do not use it } \\
\text { Once biweekly } \\
\text { Once or more daily } \\
\text { Once or more } \\
\text { weekly } \\
\text { When I feel the } \\
\text { need to }\end{array}$ & $\begin{array}{l}36 \\
9 \\
47 \\
\\
37\end{array}$ & $\begin{array}{l}23(13.0) \\
7(63.9) \\
21(44.7) \\
22(46.8) \\
15(40.5)\end{array}$ & $\begin{array}{l}13(7.3) \\
2(36.1) \\
26(55.3) \\
25(53.2) \\
22(59.5)\end{array}$ & 0.107 \\
\hline $\begin{array}{l}\text { Periodic annual visit to } \\
\text { ophthalmologist }\end{array}$ & & 145 & $71(49.0)$ & $74(51.0)$ & 0.553 \\
\hline $\begin{array}{l}\text { Cause behind first } \\
\text { ophthalmologist visit }\end{array}$ & $\begin{array}{l}\text { Symptoms } \\
\text { Other causes** }\end{array}$ & $\begin{array}{l}107 \\
69\end{array}$ & $\begin{array}{l}47(26.7) \\
4 I(23.3)\end{array}$ & $\begin{array}{l}60(34.0) \\
28(15.9)\end{array}$ & 0.045 \\
\hline
\end{tabular}

Notes: $* P$ values for Physical Exercise, Compliance to diet, and Frequency of glucose level assessment items were calculated by Chi-square testing. All other items were subjected to Fischer's exact test. **Other causes include physician instructions or self-awareness of the disease nature.

differences in educational levels of each population, economic resources, the content and quality of information provided by treating physicians and awareness raised by health care systems.

We draw the attention to an interesting discrepancy as only a minority of participants $(4.5 \%)$ recognized that DR can occur without symptoms and/or vision loss to begin with. This significant rift in understanding a fundamental concept related to DR is alarming. This phenomenon is most likely the product of poor patient awareness resulting from inadequate education measures, wherein superficial concepts related to the disease are relayed to patients, but pertinent details are left for speculation.

We furthermore found that patients' perceived awareness does not necessarily translate into their practices towards the disease. More than three quarters of the sample believed that the lack of exercise is associated with the risk to develop DM. However, almost $60 \%$ of participants never commit to any form of physical activity. This is an observation that was addressed in the diabetic literature. ${ }^{22,23}$ A similar remark was observed when the relationship between knowledge on glycemic control and frequency of checking glucose levels was probed. Such results imply that compliance towards DM's mitigating measures involves more complex interactions than that of knowledge alone.

Results of the current study offer some interesting reflections on participants' awareness of their disease and its complications. For example, sexual dysfunction is one of the most common complications of uncontrolled DM type 2 patients and according to previous reports, nearly $62 \%$ of the Jordanian patients with diabetes have a form of it, $^{24}$ yet our results demonstrate that only $4.5 \%$ of 
Table 5 Results of Binary Logistic Regression Analysis of Factors Associated with Diabetic Retinopathy

\begin{tabular}{|l|l|l|l|l|}
\hline Variable & Categories & $\begin{array}{l}\text { Odds } \\
\text { Ratio }\end{array}$ & $\mathbf{9 5 \%}$ Cl & $P$ value \\
\hline $\begin{array}{l}\text { Duration of } \\
\text { DM }\end{array}$ & $<5$ Years & & & $<0.00 I$ \\
& (Ref) & & & \\
& $5-10$ Years & 0.486 & $0.127-1.854$ & 0.265 \\
& II-20 Years & 5.352 & $1.872-15.298$ & 0.002 \\
& $>20$ Years & 8.166 & $2.445-27.277$ & $<0.001$ \\
\hline HbAIc & $<7$ (Ref) & & & 0.021 \\
& $7-7.9$ & 2.764 & $0.996-7.666$ & 0.054 \\
& $8-8.9$ & 4.666 & $1.622-13.423$ & 0.004 \\
& $>9$ & 1.520 & $0.572-4.037$ & 0.400 \\
\hline
\end{tabular}

participants comprehend sexual dysfunction as a complication of DM type 2. This lack of knowledge might be attributed to patients' thoughts of sexual dysfunction as a consequence of aging rather than as a complication of their disease.

Overall, the highest score (15 out of 20) and the mean awareness scores of our participants $(11.4 \pm 0.2)$ were unsatisfactory. This score is less than what to be expected from numbers reported by a previous study from Jordan which evaluated the general public's awareness towards DM type 2. ${ }^{25}$ Such scores demonstrate the lack of awareness in this vulnerable population. Moreover, almost half of the participants have HbAlc levels of more than $8 \%$. This further highlights the fact that most of our patients have poor control of their disease despite access to a tertiary care center, which could be a direct result of their poor awareness and/or practices, among other factors. This conclusion is endorsed by the literature wherein statistically significant associations between good awareness of DM and positive practices towards the disease were documented. ${ }^{26}$

Our study found significant associations between male gender, higher education level, employment status, HbA1c levels, dyslipidemia and higher mean awareness scores. These observations are in congruence with the available literature, where the level of education is the most consistent predictor of awareness scores. ${ }^{16,25,27,28}$ Interestingly, only the duration of DM and HbAlc levels were significantly associated with the prevalence of DR in our cohort. In fact, those variables are well-known predictors of DR development.

Our study has several limitations. Sample selection is not random which limits the generalizability of the study to DM patients or the general population. A larger sample size would improve the study's statistical power. Also, the study does not tackle patients' awareness regarding therapies of diabetes and barriers to screening. Naturally, the crosssectional nature of the study precludes causative inferences.

In conclusion, this study involving a cohort of Jordanian patients with diabetes referred for the ophthalmology service in a tertiary academic hospital uncovers that although the majority of patients acknowledge that diabetes affects the eye, their knowledge is rather superficial and most of them are unaware how DR may present. There is also a distinct rift between what they know and how their practices towards the disease reflect their alleged awareness. Visual impairment due to DR can be mitigated with early diagnosis, and patient education is the foundation of successful screening protocols. Emphasis on effective communication strategies targeting individuals with diabetes of all socioeconomic levels is of the essence to ensure that any acquired knowledge is translated into action and is reflected on their practices in real life.

\section{Data Sharing Statement}

The datasets generated and/or analyzed during the current study are available from the corresponding author upon reasonable request.

\section{Ethics Approval}

Institutional ethical approval was obtained from the Institutional Review Board at Jordan University Hospital (Ethical approval number: 278/2020/67). This research complies with the tenants of the Declaration of Helsinki. All enrolled participants provided written informed consent.

\section{Acknowledgments}

This study is funded by King Abdullah II Fund for Development. The authors would like to thank Dr. Laith Al Ejeilat and Dr. Rawand Abdel Wahed for assistance in interviewing study participants.

\section{Author Contributions}

All authors made a significant contribution to the work reported, whether that is in the conception, study design, execution, acquisition of data, analysis and interpretation, or in all these areas; took part in drafting, revising or critically reviewing the article; gave final approval of the version to be published; have agreed on the journal to which the article has been submitted; and agree to be accountable for all aspects of the work.

\section{Disclosure}

The authors report no conflicts of interest for this work. 


\section{References}

1. Wang Q, Zhang X, Fang L, Guan Q, Guan L, Li Q. Prevalence, awareness, treatment and control of diabetes mellitus among middle-aged and elderly people in a rural Chinese population: a cross-sectional study. PLoS One. 2018;13(6).

2. Alanazi FK, Alotaibi JS, Paliadelis P, Alqarawi N, Alsharari A, Albagawi B. Knowledge and awareness of diabetes mellitus and its risk factors in Saudi Arabia. Saudi Med J. 2018;39(10):981-989. doi: $10.15537 /$ smj.2018.10.22938

3. World Health Organizaiton. Jordan diabetes country profile; 2016.

4. Centers for Disease Control and Prevention. National diabetes statistics report data \& statistics diabetes CDC; 2020.

5. Fallatah MO. Knowledge, awareness, and eye care-seeking behavior in diabetic retinopathy: a cross-sectional study in Jeddah, Kingdom of Saudi Arabia. Ophthalmol Ther. 2018;7(2):377-385. doi:10.1007/ s40123-018-0147-5

6. Zheng Y, He M, Congdon N. The worldwide epidemic of diabetic retinopathy. Indian J Ophthalmol. 2012;60(5):428-431. doi:10.4103/ 0301-4738.100542

7. Abu Samra K, Al-Bdour M, Al-Till M. Risk factors for diabetic retinopathy among Jordanian diabetics. Middle East Afr J Ophthalmol. 2008;15(2):77. doi:10.4103/0974-9233.51997

8. Vijan S, Stevens DL, Herman WH, Funnell MM, Standiford CJ. Screening, prevention, counseling, and treatment for the complications of type II diabetes mellitus: putting evidence into practice. $J$ Gen Intern Med. 1997;12(9):567-580. doi:10.1046/j.15251497.1997.07111.x

9. El Khatib BA, Al Hawari HH, Al Bdour MD. Assessment of awareness of diabetic retinopathy among patients with diabetes mellitus attending the endocrine clinic at Jordan University Hospital. Madridge J Ophthalmol. 2017;2(1):17-21. doi:10.18689/mjop-1000106

10. Bakkar MM, Haddad MF, Gammoh YS. Awareness of diabetic retinopathy among patients with type 2 diabetes mellitus in Jordan. Diabetes, Metab Syndr Obes Targets Ther. 2017;10:435-441. doi:10.2147/DMSO.S140841

11. Al Zarea BK. Knowledge, attitude and practice of diabetic retinopathy amongst the diabetic patients of AlJouf and Hail Province of Saudi Arabia. J Clin Diagn Res. 2016;10(5):NC05-8.

12. Schmid KL, Schmid LM, Pedersen C. Knowledge of the ocular effects of diabetes among the general population of Australia and the members of diabetes Australia. Clin Exp Optom. 2003;86 (2):91-103. doi:10.1111/j.1444-0938.2003.tb03067.x

13. Namperumalsamy P, Kim R, Kaliaperumal K, Sekar A, Karthika A, Nirmalan PK. A pilot study on awareness of diabetic retinopathy among non-medical persons in South India. The challenge for eye care programmes in the region. Indian J Ophthalmol. 2004;52 (3):247-251

14. Funatsu H, Hori S, Shimizu E, Nakamura S. Questionnaire survey on periodic ocular examination in Japanese diabetic patients. Am $J$ Ophthalmol. 2003;136(5):955-957. doi:10.1016/S0002-9394(03) 00542-7

Clinical Ophthalmology

\section{Publish your work in this journal}

Clinical Ophthalmology is an international, peer-reviewed journal covering all subspecialties within ophthalmology. Key topics include: Optometry; Visual science; Pharmacology and drug therapy in eye diseases; Basic Sciences; Primary and Secondary eye care; Patient Safety and Quality of Care Improvements. This journal is indexed on PubMed

Submit your manuscript here: https://www.dovepress.com/clinical-ophthalmology-journal
15. Muñoz B, O’Leary M, Fonseca-Becker F, et al. Knowledge of diabetic eye disease and vision care guidelines among hispanic individuals in Baltimore with and without diabetes. Arch Ophthalmol. 2008;126(7):968-974. doi:10.1001/archopht.126.7.968

16. Sabanayagam C, Yip WF, Ting DSW, Tan G, Wong TY. Ten emerging trends in the epidemiology of diabetic retinopathy. Ophthalmic Epidemiol. 2016;23(4):209-222. doi:10.1080/09286586.2016.1193618

17. Tarboush N, Abu-Yaghi N, Al Ejeilat L, Wahed R, Jeris I.Association of Irisin circulating level with diabetic retinopathy: a case-control study. Exp Clin Endocrinol Diabetes.2018;129:36-42. doi:10.1055/ a-0723-3749

18. Abu-Yaghi NE, Abu tarboush NM, Abojaradeh AM, Al-Akily AS, Abdo EM, Emoush LO. Relationship between serum vascular endothelial growth factor levels and stages of diabetic retinopathy and other biomarkers. $J$ Ophthalmol. 2020;2020. doi:10.1155/2020/8480193

19. Kizor-Akaraiwe NN, Ezegwui IR, Oguego N, Uche NJ, AsimaduI N, Shiweobi J. Prevalence, awareness and determinants of diabetic retinopathy in a screening centre in Nigeria. $J$ Community Health. 2016;41(4):767-771. doi:10.1007/s10900-016-0151-4

20. Islam FMA, Chakrabarti R, Dirani M, et al. Knowledge, attitudes and practice of diabetes in rural Bangladesh: the Bangladesh Population based Diabetes and Eye Study (BPDES). PLoS One. 2014;9(10): e110368. doi:10.1371/journal.pone.0110368

21. Foster T, Mowatt L, Mullings J. Knowledge, beliefs and practices of patients with diabetic retinopathy at the University Hospital of the West Indies, Jamaica. J Community Health. 2016;41(3):584-592. doi:10.1007/s10900-015-0133-y

22. Memon MS, Shaikh SA, Shaikh AR, Fahim MF, Mumtaz SN, Ahmed N. An assessment of knowledge, attitude and practices (KAP) towards diabetes and diabetic retinopathy in a suburban town of Karachi. Pakistan J Med Sci. 2015;31(1):183-188.

23. López Sánchez GF, Smith L, Raman R, et al. Physical activity behaviour in people with diabetes residing in India: a cross-sectional analysis. Sci Sport. 2019;34(1):e59-66. doi:10.1016/j.scispo.2018.08.005

24. Khatib FA, Jarrah NS, Shegem NS, Bateiha AM, Abu-Ali RM, Ajlouni KM. Sexual dysfunction among Jordanian men with diabetes. Saudi Med J. 2006;27(3):351-356.

25. Alsous M, Jalil MA, Odeh M, Al KR, Alnan M. Public knowledge, attitudes and practices toward diabetes mellitus: a cross-sectional study from Jordan. PLoS One. 2019;14(3):1-12. doi:10.1371/journal.pone. 0214479

26. Srinivasan NK, John D, Rebekah G, Kujur ES, Paul P, John SS. Diabetes and diabetic retinopathy: knowledge, Attitude, Practice (KAP) among diabetic patients in a tertiary eye care centre. J Clin Diagn Res. 2017;11(7):NC01-7.

27. Alsaidan A, Ghoraba M. Awareness of diabetic retinopathy among patients with type 2 diabetes mellitus in primary health care in security forces hospital Riyadh, Saudi Arabia. J Fam Med Prim Care. 2019;8(7):2433. doi:10.4103/jfmpc.jfmpc_324_19

28. Al Shafaee MA, Al-Shukaili S, Rizvi SGA, et al. Knowledge and perceptions of diabetes in a semi-urban Omani population. $B M C$ Public Health. 2008;8:1-8. doi:10.1186/1471-2458-8-249
Central and CAS, and is the official journal of The Society of Clinical Ophthalmology (SCO). The manuscript management system is completely online and includes a very quick and fair peer-review system, which is all easy to use. Visit http://www.dovepress.com/ testimonials.php to read real quotes from published authors. 